\title{
Electrical nerve stimulation can be used as a tool in fMRI studies of pain- and tingling-evoked activations
}

\author{
Karen D Davis $\mathrm{PhD}^{1}$, Chun L Kwan $\mathrm{MSc}^{1}$, Adrian P Crawley $\mathrm{PhD}^{2}$, David J Mikulis MD ${ }^{2}$
}

KD Davis, CL Kwan, AP Crawley, DJ Mikulis.

Electrical nerve stimulation can be used as a tool in fMRI studies of pain- and tingling-evoked activations.

Pain Res Manage 2000;5(1):81-86.

OBJECTIVES/HYPOTHESES: To determine whether transcutaneous electrical nerve stimulation (TENS) provides adequate, inexpensive and simple means to image innocuous and pain-related activations in the thalamus and cortex.

SUBJECTS AND METHODS: High resolution functional magnetic resonance imaging (fMRI) was used to obtain functional data sets on a 1.5T General Electric echospeed scanner (General Electric, Milwaukee) from six axial slices during interleaved periods of rest and TENS at either nonpainful tingling or painful intensities. The volume of brain imaged allowed inspection of stimulationrelated activations in the thalamus, insula and second somatosensory cortex (S2).

RESULTS: Tingling TENS activations were identified primarily in the contralateral posterolateral thalamus. Painful TENS activations were found in the contralateral posterolateral thalamus, medial and/or anterior thalamus. The insula and S2 were activated in four of the subjects with tingling TENS and in all subjects with painful TENS. Tingling TENS activations were located in the posterior insula, whereas pain-related activations were located in the anterior insula. Painful TENS activations found in S2 overlapped with tingling TENS activations.

CONCLUSIONS: These findings demonstrate that TENS is a simple mode of stimulation that produces fairly consistent cortical activations, especially at painful levels, and thus may be useful in carefully designed and controlled clinical fMRI studies of pain and touch.

Key Words: Cortex; Functional magnetic resonance imaging; Insula; Pain; Second somatosensory cortex; Thalamus; Touch; Transcutaneous electrical nerve stimulation

\section{Neurostimulation transcutanée : outil} d'analyse dans les études d'activation de la douleur et des picotements à I'IRM

\section{fonctionnelle}

OBJECTIF/HYPOTHÈSE : Vérifier si la neurostimulation transcutanée (NT) offre un moyen simple, adéquat et économique de visualiser des signes d'activation inoffensive, liée à la douleur dans le thalamus et le cortex.

SUJETS ET MÉTHODE : On a eu recours à l'imagerie par résonance magnétique fonctionnelle (IRMf) à haute résolution pour obtenir des ensembles de données fonctionnelles sur un tomodensitomètre écho 1.5 de General Electric (Milwaukee) à partir de six coupes axiales durant des périodes entrecoupées de repos et de NT à des niveaux d'intensité provoquant soit des picotements non douloureux, soit de la douleur. La grosseur de l'image du cerveau permettait de visualiser les signes d'activation liée à la stimulation dans le thalamus, l'insula et la

voir page suivante 
deuxième zone somato-sentitive (S2) du cortex.

RÉSULTATS : Les signes d'activation des picotements par la NT ont été enregistrés surtout dans le thalamus postéro-latéral controlatéral, et ceux de la douleur, dans le thalamus postéro-latéral controlatéral, le thalamus central et le thalamus antérieur. L'insula et la S2 ont été activées chez quatre des sujets soumis à l'activation des picotements et chez tous les sujets soumis à une intensité douloureuse. La zone d'activation des picotements se trouvait dans l'insula postérieure, tandis que la zone d'activation de la douleur se trouvait dans l'insula antérieure. Les zones d'activation de la douleur, enregistrées dans la S2, se superposaient aux zones d'activation des picotements.

CONCLUSION : Les résultats obtenus montrent que la NT offre un mode simple de stimulation qui engendre une activation corticale relativement constante, surtout aux intensités douloureuses; la NT pourrait donc s'avérer utile dans les études cliniques, contrôlées et soigneusement conçues d'IMR fonctionnelle portant sur la douleur et le toucher.
A scending nociceptive and non-nociceptive pathways are classically thought to relay in one or more regions of the thalamus, and then ascend to multiple cortical regions such as the primary (S1) and the secondary (S2) somatosensory cortices, the insula cortex and the anterior cingulate cortex (ACC) (1-3). Advances in functional neuroimaging technologies have facilitated the study of thalamic and cortical representation of touch and pain in normal human subjects (4-11). These technologies offer the potential for the study of patients with altered somatosensory function. However, functional imaging in a clinical setting requires a mode of stimulation that is simple, safe, relatively inexpensive and can produce reliable results. We recently demonstrated that thermal stimuli can activate pain and thermal pathways, but that they require a specially designed MRI-compatible, computer-controlled, thermal stimulator. Furthermore, the ensuing results were hampered by intersubject variability $(11,12)$, in part because of the variable, overall psychophysical experience evoked by noxious heat and cold stimuli. In contrast, our early studies of ACC and S1 function demonstrated that transcutaneous electrical nerve stimulation (TENS) of the median nerve is compatible with functional magnetic resonance imaging (fMRI) and can be used to study innocuous tingling and pain-related cortical activation in normal human subjects $(6,9)$. Because TENS is a relatively inexpensive, simple mode of activating low and high threshold afferents, it may be a valuable tool to assess touch- and pain-evoked brain activation. Therefore, the present study sought to test the applicability of TENS in studies of innocuous systems and pain systems by expanding our knowledge of individual TENS-evoked pain activations beyond $\mathrm{S} 1$ and ACC to other cerebral structures, namely the thalamus, insula and S2 cortex, which are presumed to play a role in touch and pain perception.

\section{SUBJECTS AND METHODS}

Subjects: Six healthy subjects (five male, one female) were recruited from students and staff at the University of Toronto and Toronto Hospital, Toronto, Ontario. Subjects ranged in age from 30 to 37 years and were all right-handed. All subjects gave informed consent to procedures approved by the University of Toronto Human Subjects Review Committee. Each subject was then familiarized with the TENS stimulation equipment and given test stimuli to ensure that the electrodes were adequately placed to evoke tingling and pain in the hand at intensities that were tolerable. The experimental protocol was fully explained to each subject so that they understood that the stimuli would be cycling on and off every 39 s throughout imaging.

TENS stimulation: A clinical Direct Current-powered neuromuscular stimulator (Medtronic respond II, model 3128, [Medtronic, Minneapolis]) was used to deliver TENS to the right median nerve. Details of the TENS stimulation device and safety precautions for use in an MRI environment have been previously published $(6,9)$. Long leads (approximately $6.1 \mathrm{~m}$ ), housed in plastic tubing to help prevent looping of the wires, were used briefly to distance the TENS unit far from the bore of the MRI. The device delivered continuous trains of stimuli at $50 \mathrm{~Hz}$ that were cycled on and off at $39 \mathrm{~s}$ intervals. Before imaging, each subject selected a stimulus intensity that evoked nonpainful tingling sensations and higher intensity that evoked painful sensations. Subjects were instructed to attend to the stimuli and to be prepared to give a verbal rating of the pain intensity following the test.

Imaging sequences: Subjects were positioned supine on the MRI table and their heads stabilized in the head coil with pillows and foam padding. Care was taken to ensure that the subjects were as comfortable as possible to help reduce head movement; lights were dimmed, a support was placed under their knees if desired, and they were told to relax and keep their eyes closed throughout the imaging. Functional images were acquired with a spiral sequence $(13,14)$ on a $1.5 \mathrm{~T}$ General Electric echospeed MRI system. Slice locations were planned from a sagittal localizer to allow inspection of the thalamus, S2 and insula. Six $4 \mathrm{~mm}$ thick contiguous axial slices parallel to the anterior (AC) and posterior (PC) commissures line were selected, the most inferior slice 0 to $2 \mathrm{~mm}$ superior to the AC-PC line. Functional activation maps were overlayed onto high resolution images (T2-weighted, fast spin echo or T1-weighted spoiled gradient recalled echo). Functional sequence parameters were: field of view $22 \times 22$ $\mathrm{cm}$, in plane resolution $1.7 \mathrm{~mm} \times 1.7 \mathrm{~mm}$, TE $40 \mathrm{~ms}$, TR $480 \mathrm{~ms}$, four interleaves, $1.92 \mathrm{~s} / \mathrm{vol}, 140$ to 160 images/slice location/task.

Experimental protocol: Each subject underwent a 'tingling TENS' experimental session followed by a 'painful TENS' experimental session. There was approximately 5 to $10 \mathrm{mins}$ of rest (no stimulation) between these sessions. In each of these experiments, sequences consisted of seven to eight cycles of 'no stimulation' (39 s) and 'TENS stimulation' (39 s). The first images of each sequence were obtained with the stimulator off. To avoid undue movement artifacts during im- 
TABLE 1

Individual pain ratings and activations across all modalities

\begin{tabular}{|c|c|c|c|c|c|c|c|c|c|}
\hline \multirow{2}{*}{$\begin{array}{c}\text { Subject } \\
\# \text {-sex } \\
\end{array}$} & \multicolumn{4}{|c|}{$\begin{array}{l}\text { Tingle TENS } \\
\text { activations }\end{array}$} & \multicolumn{4}{|c|}{$\begin{array}{l}\text { Painful TENS } \\
\text { activations }\end{array}$} & \multirow[t]{2}{*}{$\begin{array}{l}\text { Pain intensity } \\
\text { rating }\end{array}$} \\
\hline & $\mathrm{T}$ & I & S2 & BG & $\mathrm{T}$ & I & S2 & BG & \\
\hline $1-M$ & & & घ & & 口 & घ & 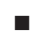 & & 5.0 \\
\hline $2-M$ & घ & घ & ! & घ & घ & घ & $\square$ & & 7.5 \\
\hline $3-M$ & घ & & - & घ & - & घ & $\square$ & & 5.0 \\
\hline $4-\mathrm{F}$ & घ & घ & - & & & घ & घ & & 7.0 \\
\hline $5-M$ & घ & घ & & - & घ & - & घ & $\square$ & 6.5 \\
\hline $6-M$ & घ & घ & & घ & घ & घ & घ & घ & 7.0 \\
\hline
\end{tabular}

* Mean $\pm S E$; - Activation identified in a particular brain region during a given task. BG Basal ganglia (caudate, putamen or globus pallidus); I Insular cortex; S2 Secondary somatosensory cortex; T Thalamus; TENS Transcutaneous electrical nerve stimulation

aging, a verbal rating of pain intensity was obtained from the subject after the painful TENS sequence. The subject was asked to rate the intensity of pain on a scale from zero (no pain) to 10 (most intense pain imaginable) for the entire sequence. Subjects specifically questioned the individual pain intensities and noted that the pain intensity did not differ much from trial to trial within the painful TENS sequence. This was substantiated in a psychophysical session where subjects continuously rated pain intensity during painful TENS similar to that used in the imaging session. In this separate, nonimaging session, subjects used a continuous rating program (Medoc TSA2001, COVAS system [Medoc Ltd, Israel]) to rate the experimental pain stimuli delivered in the same manner as the imaging session.

Analysis: Functional images were realigned using automated image registration $(15,16)$ to correct for motion. Images were also visually inspected for motion artifacts by using cinematic loop and data from subjects with overt movement artifacts were discarded from further analysis. Functional images were submitted to a pixel by pixel statistical analysis (Stimulate, JP Strupp, Minneapolis), where the signal intensity of each pixel was correlated to a 'boxcar' plot of the interleaved periods of TENS ('on') versus no stimulation ('off'). The criteria used to accept pixels as activations have been detailed in previous studies $(11,12)$. Briefly, all task-related activations met the following three conditions: a statistically significant signal intensity change of $\mathrm{P}<0.05$ (corrected for multiple comparisons); situated only on grey matter; and signal intensity profiles had a 'sawtooth-like' pattern of signal increases and decreases in at least $75 \%$ of task repetitions $(11,12)$. Task-related activations were reconstructed onto representative maps based on standardized brain maps (17). The reconstructed activations were submitted for analysis by using either a Student's $t$ test or MannWhitney $\mathrm{U}$ test to determine possible differences in the incidence of activations within given brain regions between painful and nonpainful TENS. A Fisher's Exact test was used

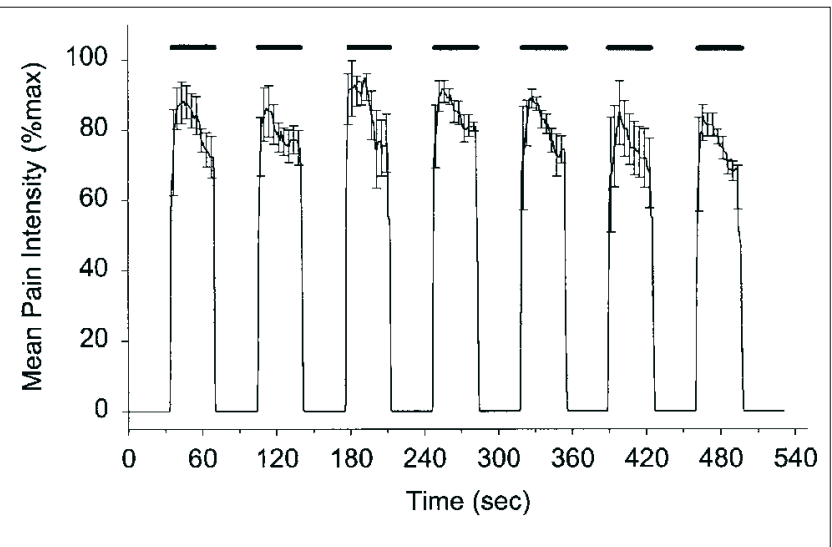

Figure 1) Mean pain ratings ( $\pm \mathrm{SE}$ ) are shown for painful transcutaneous electrical nerve stimulation-evoked responses obtained during the psychophysical sessions. Individual data were normalized by each subject's maximum pain intensity rating and then averaged across subjects

to compare the proportions of subjects exhibiting activations within a given brain region.

\section{RESULTS}

TENS stimuli were tolerated well by all subjects at both tingling and painful levels. According to subjective reports obtained after the imaging sessions, the TENS intensity used for the 'tingling' sessions evoked only nonpainful sensations. TENS-evoked sensations projected primarily to the peripheral distribution of the median nerve in the lateral hand area, although sometimes prickling was noted also at the electrode sites during painful TENS. The overall rating of pain intensity evoked during each imaging session was $6.3 \pm 0.4$ (mean \pm SE). Individual subject ratings for pain evoked during imaging are shown in Table 1. Further psychophysical testing of the time course of TENS-evoked pain conducted in a separate, nonimaging session revealed that pain was evoked throughout each stimulus block with little or no interstimulus interaction between trial blocks (Figure 1).

The incidence and distribution of thalamic, insula and S2 activations are shown in Tables 1 and 2, and a composite of all activations is represented in Figure 2. These activations represent only pixels that met the statistical criteria and activation profile described in the methods. Thalamic activation was detected in all but one subject during tingling and painful intensities of TENS (Table 1). Tingling TENS activations were concentrated in the contralateral posterolateral part of the thalamus, although some activations also were noted ipsilaterally. The painful TENS activations also were concentrated on the contralateral side with some bilateral activations. Many of the pain activations were located in the posterolateral region but also were identified in the medial thalamus and anterior thalamus. Although there was overlap between tingling- and pain-evoked activations in some subjects, the pain activations typically encompassed an enlarged region or some separate voxels compared with the tingling activations. An example of a subject with non-overlapping 
TABLE 2

Incidence of activations

\begin{tabular}{|c|c|c|}
\hline & Tingling TENS & Painful TENS \\
\hline Thalamus & $\begin{array}{c}83 \% \\
3 / 6 \mathrm{c} \\
1 / 6 \mathrm{i} \\
1 / 6 \mathrm{bi}\end{array}$ & $\begin{array}{c}83 \% \\
3 / 6 \text { c } \\
- \\
2 / 6 \text { bi }\end{array}$ \\
\hline Insula & $\begin{array}{c}67 \% \\
3 / 6 \mathrm{c} \\
- \\
1 / 6 \mathrm{bi}\end{array}$ & $\begin{array}{c}100 \% \\
3 / 6 \mathrm{c} \\
- \\
3 / 6 \mathrm{bi}\end{array}$ \\
\hline Anterior insula & - & $5 / 6^{*}$ \\
\hline Posterior insula & $4 / 6$ & $-^{*}$ \\
\hline $\begin{array}{l}\text { Anterior }+ \text { posterior } \\
\text { insula }\end{array}$ & - & $1 / 6$ \\
\hline S2 & $\begin{array}{c}67 \% \\
1 / 6 \text { c } \\
- \\
3 / 6 \text { bi }\end{array}$ & $\begin{array}{c}100 \% \\
1 / 6 \mathrm{c} \\
- \\
5 / 6 \mathrm{bi}\end{array}$ \\
\hline Basal ganglia & $\begin{array}{c}67 \% \\
1 / 6 \mathrm{c} \\
3 / 6 \mathrm{i} \\
-\end{array}$ & $\begin{array}{c}33 \% \\
- \\
1 / 6 \mathrm{i} \\
1 / 6 \mathrm{bi}\end{array}$ \\
\hline
\end{tabular}

* Statistical difference between incidence of tingling and pain-evoked activation at $P<0.05$ (Fisher's exact test). bi Bilateral; $c$ Contralateral only; $i$ Ipsilateral only; TENS Transcutaneous electrical nerve stimulation

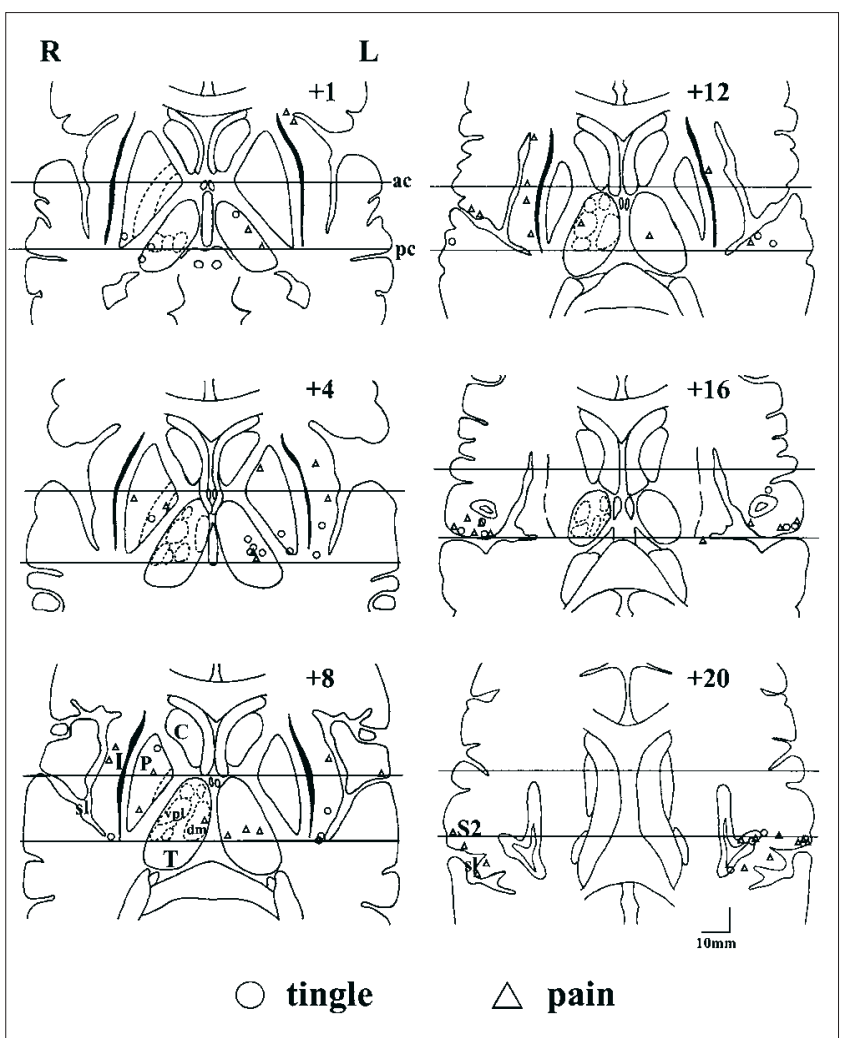

Figure 2) The location of innocuous tingling transcutaneous electrical nerve stimulation-related (circles) and painful transcutaneous electrical nerve stimulation-related (triangles) activations for all subjects are indicated on line drawings based on standardized brain maps (17). The horizontal lines in each map represent the lines through the anterior (ac) and posterior (pc) commissures. C Caudate; dm Dorsal medial nucleus; I Insula; sl Lateral sulcus; L Left brain; P Putamen (note: globus pallidus is located medial to the putamen); R Right brain; S2 Second somatosensory area; T Thalamus; vpl Ventroposterior lateral nucleus;
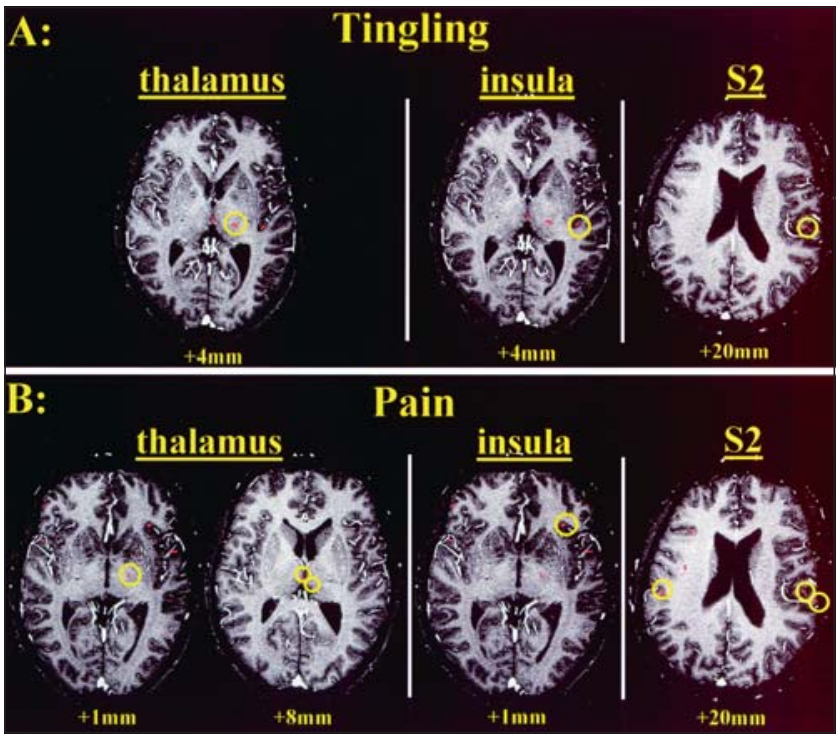

Figure 3) Examples of nonoverlapping regions of activation in the thalamus, insula and S2 (highlighted by yellow circles) during TENS-evoked tingling (A) and pain (B). Functional images are shown for the thalamus and insula in subject \# 2 and for the S2 in subject \#3.

tingling and pain activations is shown in Figure 3. In this subject, the tingling TENS activated the posterolateral thalamus, whereas the painful TENS activated the medial and anterior thalamus.

The insula and S2 were activated in $67 \%$ of subjects during the tingling TENS. S2 activations were located either contralaterally or bilaterally. All tingling-related activations were located in the posterior insula, either contralaterally or bilaterally. There were no tingling-evoked activations in the anterior insula. In contrast, the painful TENS activated the anterior insula and S2 in all subjects; however, one subject had pain-related activations in both the anterior and the posterior insula. An example of the distinction between anterior and posterior insula activations is shown in Figure 3. Furthermore, pain-related $\mathrm{S} 2$ activations were typically more extensive, and frequently included multiple activations (Figure 3).

Tingling- and pain-related activations also were noted in the contralateral or ipsilateral basal ganglia in some subjects. The distribution of these activations included the globus pallidus and the putamen (Figure 3).

\section{DISCUSSION}

The study provides further evidence that fMRI and TENS can be used as a tool to investigate the pain and touch pathways in individual subjects. The TENS protocol may be particularly suitable for future clinical studies of pain and sensory loss because of its simplicity, low cost and ability to deliver repeated stimuli without the confounds of tissue damage, habituation or sensitization.

In our previous studies $(11,12)$ of the cortical effects of pain evoked by either noxious heat or noxious cold stimuli, we reported notable intersubject variability in pain-related responses. This may have resulted from variable sensory and 
pain experiences evoked by these modes of stimulation. Pain evoked by noxious thermal stimuli or mechanical stimuli is dependent on excitation of cutaneous heat-sensitive or mechanically sensitive nociceptors, and also on subsequent complex, central processing of peripheral inputs. In this study, the TENS stimuli would bypass the cutaneous receptors and directly excite a variety of primary afferent nociceptors along the course of their axons. Furthermore, in contrast to thermal stimuli that would excite only nociceptors subserving a circumscribed region of the skin under the probe (approximately $30 \mathrm{~mm} \times 30 \mathrm{~mm}$ ), a larger number of nociceptors could presumably be excited by TENS because the stimuli are applied directly to the median nerve. Therefore, the TENS technique is a valuable tool for studies that address general questions concerning central processing of pain. However, a word of caution in the interpretation of fMRI results is warranted because the presence of reported activations is based on statistical criteria. For instance, a poor signal to noise ratio and/or conservative statistical cutoff can affect negative findings. Therefore, the lack of a detectable fMRI response cannot be associated with the lack of neuronal activity with absolute certainty.

This study also identified some overlap in the spatial patterns of activation evoked by nonpainful and painful TENS, particularly in the lateral thalamus and the S2. These data confirm anatomical and electrophysiological primate studies (18-24) and a previous human imaging study (4) that demonstrated both low and high threshold inputs to these regions. Because fMRI is an indirect measure of the neuronal and

\section{REFERENCES}

1. Craig AD, Dostrovsky JO. Processing of nociceptive information at supraspinal levels. In: Anesthesia: Biologic foundations. Yaksh TL, Lynch C, Zappol WM, eds. Philadelphia: Lippincott Williams \& Wilkins Publishers. 1997:625-42.

2. Willis WD, Westlund KN. Neuroanatomy of the pain system and of the pathways that modulate pain. J Clin Neurophysiol 1997;14:2-31.

3. Berkley KJ, Hubscher CH. Are there separate central nervous system pathways for touch and pain. Nat Med 1995;1:766-73.

4. Coghill RC, Talbot JD, Evans AC, et al. Distributed processing of pain and vibration by the human brain. J Neurosci 1994; 14:4095-108.

5. Iadarola MJ, Berman KF, Zeffiro TA, et al. Neural activation during acute capsaicin-evoked pain and allodynia assessed with PET. Brain 1998;121:931-47.

6. Davis KD, Taylor SJ, Crawley AP, Wood ML, Mikulis DJ. Functional MRI of pain- and attention-related activations in the human cingulate cortex. J Neurophysiol 1997;77:3370-80.

7. Talbot JD, Marrett S, Evans AC, Meyer E, Bushnell MC, Duncan GH. Multiple representations of pain in human cerebral cortex. Science 1991;251:1355-8.

8. Svensson P, Minoshima S, Beydoun A, Morrow TJ, Casey KL. Cerebral processing of acute skin and muscle pain in humans. J Neurophysiol 1997;78:450-60.

9. Davis KD, Wood ML, Crawley AP, Mikulis DJ. fMRI of human somatosensory and cingulate cortex during painful electrical nerve stimulation. Neuroreport 1995;7:321-5.

10. Peyron R, García-Larrea L, Grégoire MC, et al. Allodynia after lateral-medullary (Wallenberg) infarct - A PET study. Brain 1998;121:345-56.

11. Kwan CL, Crawley AP, Mikulis DJ, Davis KD. An fMRI study of the anterior cingulate cortex and surrounding medial wall activations synaptic activity within a volume of brain tissue (ie, as defined by the slice thickness and in-plane resolution), a more precise distinction in the location of regions subserving pain versus touch in humans requires study at the single neuron level. The relatively small voxel size in this study was advantageous to identify clearly some functional specificity in regions such as the medial thalamus and anterior insula that were activated with painful but not innocuous levels of TENS. These data support our previous fMRI study (12) that demonstrated that pain-specific regions are evoked by noxious thermal stimuli. Pain-responsive neurons have been identified in the anterior insula and the medial thalamus in the monkey $(1,25)$. Therefore, although pain and touch systems clearly share some central pathways, there also are distinct thalamic and cortical sites that subserve only pain functions. The exact nature of these pain functions cannot be extracted from the current data, but future imaging investigations should provide insight into the contribution of specific thalamocortical regions in sensory-discriminative, motivationalaffective and reflexive dimensions of the pain experience.

\section{CONCLUSIONS}

We have demonstrated that TENS is a simple mode of stimulation that can be used in fMRI studies of pain and touch.

ACKNOWLEDGEMENTS: The authors thank Michelle Shapiro for technical assistance. This study was supported by a grant to $\mathrm{Dr}$ Davis from the Medical Research Council of Canada.

evoked by noxious cutaneous heat and cold stimuli. Pain 2000;85:359-74

12. Davis KD, Kwan CL, Crawley AP, Mikulis DJ. Functional MRI study of thalamic and cortical activations evoked by cutaneous heat, cold and tactile stimuli. J Neurophysiol 1998;80:1533-46.

13. Meyer CH, Hu BS, Nishimura DG, Macovski A. Fast spiral coronary artery imaging. Magn Reson Med 1992;28:202-13.

14. Glover GH, Lee AT. Motion artifacts in fMRI: Comparison of 2DFT with PR and spiral scan methods. Magn Reson Med 1995;33:624-35.

15. Woods RP, Grafton ST, Holmes CJ, Cherry SR, Mazziotta JC. Automated image registration: I. General methods and intrasubject, intramodality validation. J Comput Assist Tomogr 1998;22:139-52.

16. Woods RP, Grafton ST, Watson JD, Sicotte NL, Mazziotta JC. Automated image registration: II. Intersubject validation of linear and nonlinear models. J Comput Assist Tomogr 1998;22:153-65.

17. Talairach J, Tournoux P. Co-planar stereotaxic atlas of the human brain: An approach to cerebral imaging. Germany: Thieme Medical Publishers Inc, 1988:1-122.

18. Chung JM, Lee KH, Surmeier DJ, Sorkin LS, Kim J, Willis WD. Response characteristics of neurons in the ventral posterior lateral nucleus of the monkey thalamus. J Neurophysiol 1986;56:370-90.

19. Apkarian AV, Shi T. Squirrel monkey lateral thalamus. I Somatic nociresponsive neurons and their relation to spinothalamic terminals. J Neurosci 1994;14:6779-95.

20. Kenshalo DR Jr, Giesler GJ Jr, Leonard RB, Willis WD. Responses of neurons in primate ventral posterior lateral nucleus to noxious stimuli. J Neurophysiol 1980;43:1594-614. 
21. Ralston HJ III, Ralston DD. Medial lemniscal and spinal projections to the macaque thalamus: an electron microscopic study of differing GABAergic circuitry serving thalamic somatosensory mechanisms. J Neurosci 1994;14:2485-502.

22. Sinclair RJ, Burton H. Neuronal activity in the second somatosensory cortex of monkeys (Macaca mulatta) during active touch of gratings. J Neurophysiol 1993;70:331-50.

23. Krubitzer L, Clarey J, Tweedale R, Elston G, Calford M. A redefinition of somatosensory areas in the lateral sulcus of macaque monkeys. J Neurosci 1995;15:3821-39.

24. Dong WK, Salonen LD, Kawakami Y, Shiwaku T, Kaukoranta M, Martin RF. Nociceptive responses of trigeminal neurons in SII-7b cortex of awake monkeys. Brain Res 1989;484:314-24.

25. Dostrovsky JO, Craig AD. Nociceptive neurons in primate insular cortex. Soc Neurosci 1996;22:111. (Abst) 


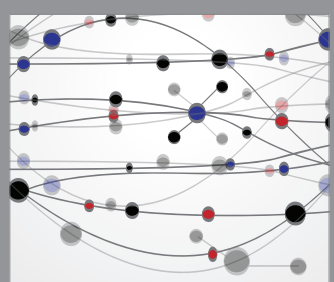

The Scientific World Journal
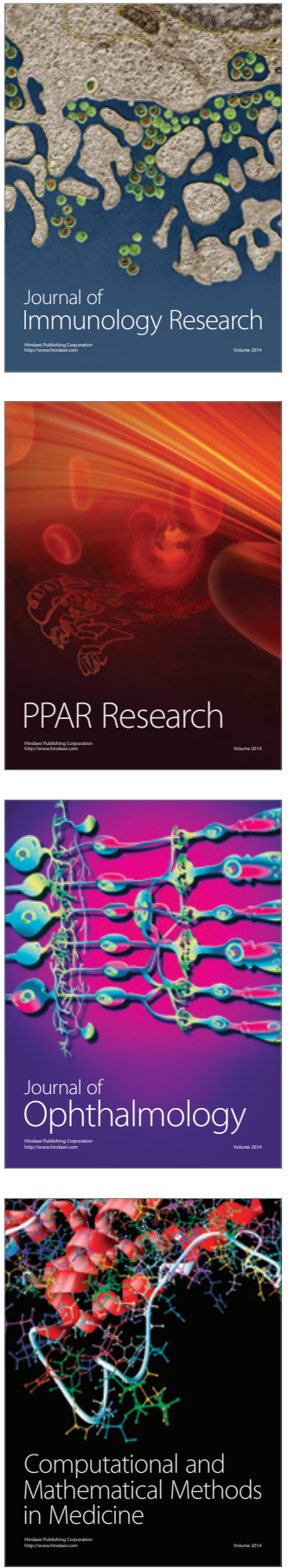

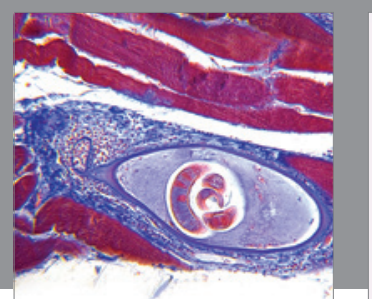

Gastroenterology Research and Practice

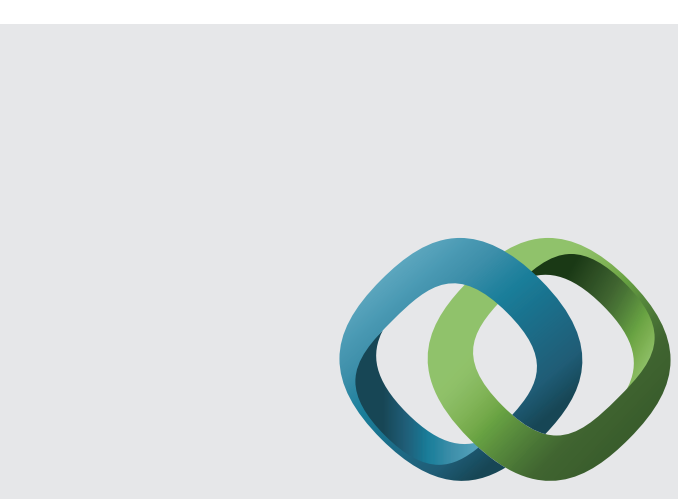

\section{Hindawi}

Submit your manuscripts at

http://www.hindawi.com
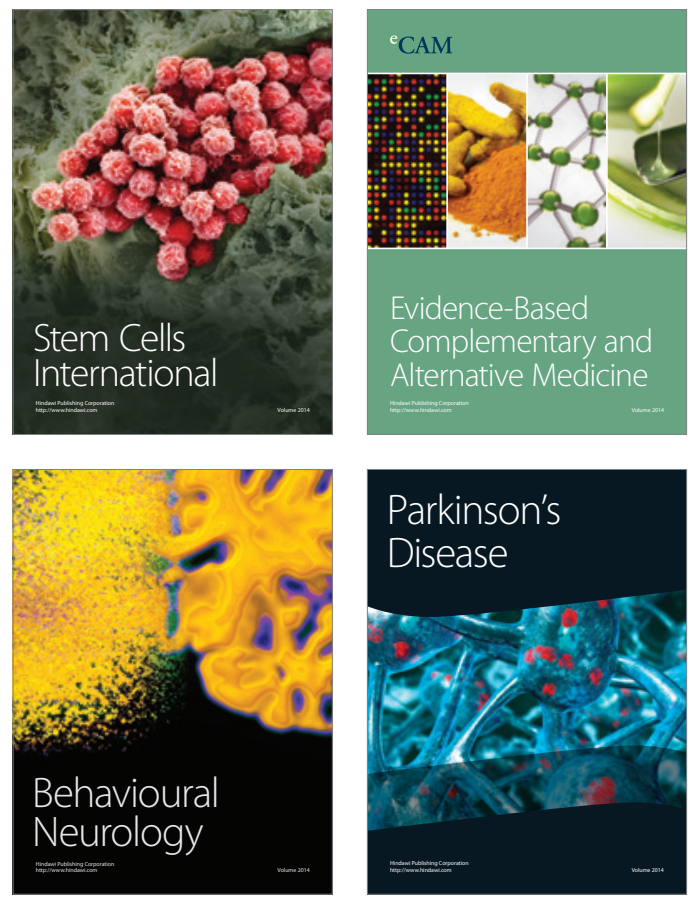
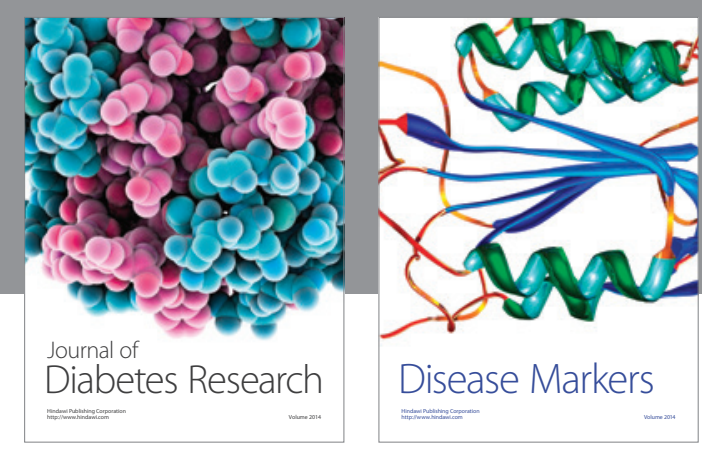

Disease Markers
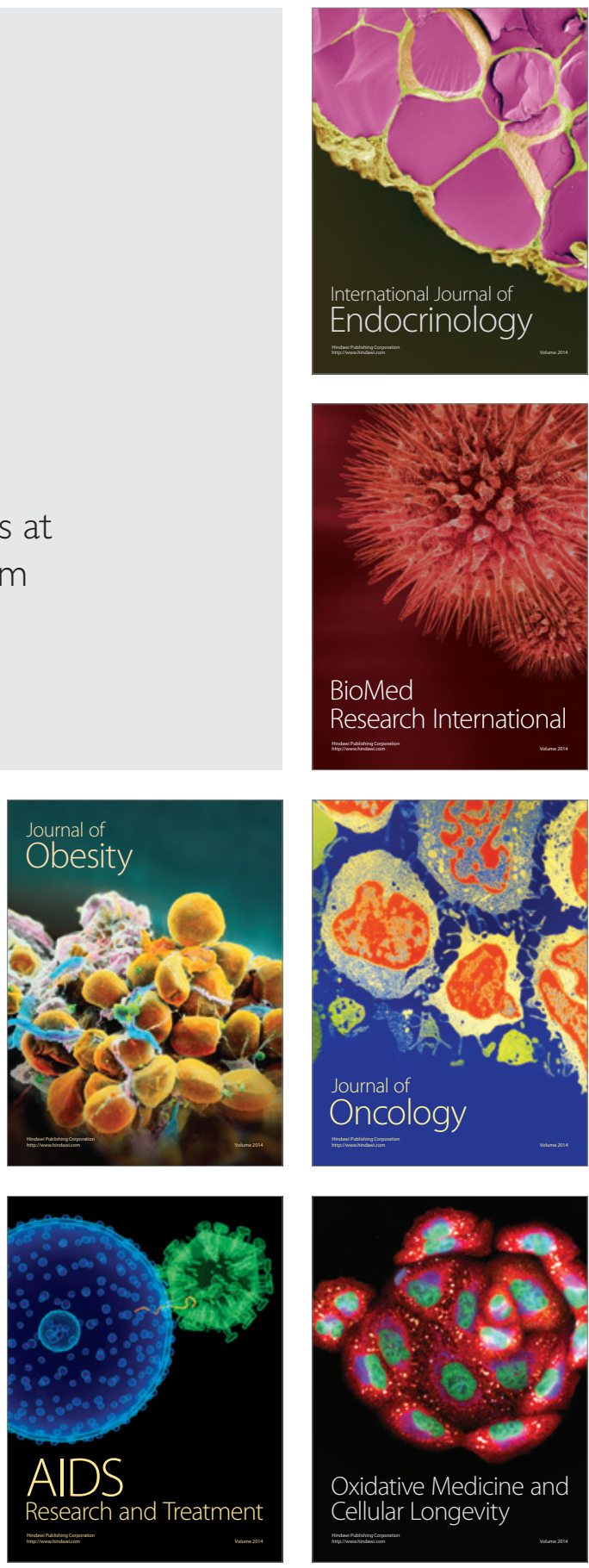